\title{
Developing English Speaking Material Based on Contextual Teaching and Learning (CTL) for Junior High School Students
}

\author{
Agustina Wulandari ${ }^{1, *}$ Erni Yusnita ${ }^{2, *}$ Suci Nuralita Sari ${ }^{3}$ \\ ${ }^{123}$ Magister Students of Universitas Jambi \\ *Corresponding author.Email:1wulandari.agustina2294@gmail.com 2erniyusnita1996@gmail.com \\ 3ucinuralita@gmail.com
}

\begin{abstract}
In daily life, language occupies the most important aspect because it is a means of communication among humans. With the existence of language, there are many things humans can do in expressing the ideal of liking and disliking discovering the world, and other things. In order to be able to communicate in global community we need to learn International languages. One of the International languages is English. There are four skills that should be mastered in English. The most important skill is speaking. The success in teaching and learning speaking is influenced by some factors, one of them is learning material. The materials should be contextualized to the experience, realities and first languages of the learners to help learners acquire the language easier. In this paper the researchers present the way how to develop speaking material for junior high school students based on Contextual Teaching and Learning. This paper hopefully can contribute to the betterment of teaching and learning speaking in practice.
\end{abstract}

Keyword: Speaking, Contextual Teaching and Learning, Material.

\section{INTRODUCTION}

In daily life, language occupies the most important aspect because it is a means of communication between humans. One of the most popular languages is English, which is an international language. This is what makes learning English useful. in Indonesia, English is known as a foreign language, it makes some junior high school students not recognize it [1]. According to (Manurun and Izzar, 2019)[2], In Indonesia, English lessons are fundamental to the needs presented by the world to see the culture and development of science and technology.. In short, English become general language for everyone around the word to know each culture, technology and develop business.

When studying a language, the main goal is that students are able to communicate using the language. It means that the main learning objective that must be achieved in learning English is communication, focusing on speaking skill. Richard and Renandya, 2002 (as cited in Kurniawan, 2020)[3] said that the most important element in communication, namely speaking. the success of the teaching and learning process, especially speaking, has several factors that affect it, namely the material. students studying English as a second language need a lot of support in every class. At the start of the school year, ESL students will provide a list of specific modifications recommended for them. Likewise with intermediate and advanced students, the teacher will adjust the content area according to the student's needs and interest by making modifications in the material given. As such, it is important to use appropriate learning material that can assist students' skill in speaking English and students' learning in any content area based on their needs and their interest. It is necessary for teachers to develop material based on student needs so that learning objectives are more easily achieved. One of popular approach in teaching speaking is Contextual Teaching and Learning (CTL) According to Smith (as cited in Annisa, 2015) [4] With CTL the concept of learning is more active where students are practicing in speaking activities. student activity in the form of exploration, investigation, validation and discussion.

As said above, material is one of the factors that support the students speaking skills. The material presented to students must be interesting, accordance 
with students' need and the learning objective. Learning is categorized as successful if it can achieve the learning objectives that have been set. Materials used by teachers in teaching English have an important role in achieve learning objectives. Appropriate material can help the teacher and the students achieve the learning objective successfully. On the other words, inappropriate material can cause the purpose of teaching and learning process unsuccessful. Sometimes, materials taught are not in accordance with the students need and interest so that learning objectives are not achieved successfully.

From the explanation above, it is important to develop speaking material for students in order to help students find what they need and interest. Moreover, the development also used to successfully achieve the learning objectives of teaching and learning. Appropriate material is a material that contextual to students' environment so that students become more motivated to learn. Besides that, the material taught must also be able to encourage students to be more active and creative in learning and produce a project that is useful for developing their speaking skills.

\section{LITERATURE REVIEW}

Speaking is one of the four skills in English subject as a tool to communicate each other. According to Nakhalah [5] In speaking, the parts of the body that play an active role, namely the mouth, then emit sounds using the lungs, vocal cords, tongue, teeth and lips. Based on its achievements, speaking is divided into two types, namely good talk and bad talk, this is based on what aspects are discussed. Harris [6] says that there are several aspects in language, Pronunciation, Grammar, Vocabulary, Fluency and Comprehension. the CTL approach is a language learning strategy, especially in teaching speaking. it emphasizes the process of student involvement in finding material and relating it to the real situation and applying it in everyday life. [7]. Teaching English not only based on the course book that usually used, but also teaching English with contextual materials is important. The materials should develop and design from the students' daily life context like, culture, economy, physic environment, as well as psychology, because contextual teaching and learning. It is suitable to the English learning objectives in curriculum that junior high school students have to master the functional skill to solve their daily life related with English. As the learning strategy, CTL determines planning of whole activities that designed to achieve the instructional objectives. Contextual teaching and learning is defined as a conception of teaching and learning that helps teachers connect the subject to the real situation (united states department of education office of vocational and adult education in Smith [8]. Contextual teaching as an innovative instructional process that helps students relate the contents of learning to the real context in which content will use. This concept should use in the classroom to make the students catch the material easier and make the material useful for the students directly.

In the teaching and learning process, there are several materials that will be delivered or taught by the teacher to the students. In formal learning, these materials are taken based on the curriculum used in the educational unit and have a time limit to achieve the targets or learning objectives of each material. Tomilinsen in Suseno [9] said material refers to something that is used by teachers or students which aims to facilitate learning and is able to increase knowledge and experience of students. the usual material is in the form of books, pictures, charts, tapes, videos and others.

Harwood [10] comments that very often teachers do not choose their own course book or other material because in many contexts they are prescribed at a higher level, for example by the institution's administrations or by a Ministry of Education. In teaching and learning, it is important for the teacher to choose the best material based on the students need and what kind of learning objective that want to achieved. However, sometimes teacher do not choose their material by themselves.

Hotchinson and Waters [11] explain that a material is said to be good, if it contains interesting text, fun activities that can involve students to think independently, and provide opportunities for students to use existing knowledge and skills. In addition, good material must also provide a clear and coherent unit structure, it is meant that the material can guide teachers and students in maximizing learning activities. Moreover Jolly and Bolitho in Sinaga [12] say "Materials should be contextualized to the experience, realities and first languages of the learners. An important part of this involves awareness on the part of the teacher-designer of the 'socio-cultural approciacy' of things such as the designer's own style of presenting material, of arranging groups, and so on.

Jolly and Bolitho (in Sinaga)[12] propose material writing model as follow:

1) Identification of need for materials

The problem that face by the students and the way to solve that problem.

2) Explanation of need

It means that the researcher as developer have to explore the problem area in the case of language forms, language function and think how the material can help students in learning process.

3) Contextual realization of material

The material that prepared has to be suitable with the culture, needs and students daily knowledge or activity.

4) Pedagogical realization material

This step involves the use of instruction and appropriate exercise and activities to enable 
the achievement of the goals using materials that have been identified and selected.

5) Production of material

The material will be developed including speaking materials as content, the layout, visual and the size.

6) Students use of material

After finishing the materials, the next step is students' use of material. This step is optional, it can be done or not. This step is done to know the impression of the students.

7) Evaluation of the material

The last step is evaluating the material by expert judgment. The expert will evaluate the material and give good advice to make the material better.

\section{DISCUSSION}

The aim of this paper is to develop English learning material especially in speaking skills for the junior high school level. The authors have designed the material development for speaking using CTL theory. Where the CTL has been used a lot of success by previous authors. Teaching English is not only based on the course book that usually used, but also teaching English with contextual materials is important. The materials should develop and design from the students 'daily life context like, culture, economy, physical environment, as well as psychology, because contextual teaching and learning CTL is a learning strategy that emphasizes students' involvement process to find the material and relate it to the real situation in order to elaborate students implement in their daily life. The author hopes that this research plan can be better and can achieve the learning objectives; especially students are able to speak using English in accordance with learning objectives.

\section{CONCLUSION}

Speaking is one of the most important skills in the four skills of English. Speaking is also a skill that must be mastered by students, especially at the junior high school level. In the learning process, speaking material must support students in the learning process, but in school the teacher must provide learning based on the curriculum and English textbooks. In the English book, it is not yet fully possible for students to communicate using English properly and the material presented in the book is not yet suitable for what is needed by students and the material contained in the book is not contextual in the student environment. Therefore, the authors uses CTL theory to develop speaking material. CTL is a theory that can help writers develop English learning materials, especially in speaking skills, because CTL theory can help develop material so that it is more interesting and more contextual.

\section{REFERENCES}

[1] Hetrakul. (1995). The Second Language. Retrieved from

http://eserver.org/courses/spring95/76100/KavinH etrakul.html

[2] Manurung, Y. H. and Izar, S. L. (2019), Challenging Factors Affecting Students' Speaking Performance, University of Muhammadiyah Sumatera Utara

[3] Kurniawan, M. A. (2020). Improving the Students' Speaking Ability through Project-Based Learning. Bachelor Thesis, Muhammadiyah University of Makassar.

[[4] Annisa, S. (2015). Teaching Speaking in English Using Contextual Teaching and Learning. English Education Journal (EEJ), 6(4): 497-510

[5] Nakhalah, A. (2016). Problems and Difficulties of Speaking that Encounter English Language. Al Quds University.

[6] Harris, D. (1974). Testing English as a Second Language. New York: Mc. Graw. Hill Book Company.

[7] Sukmadinata, N. S. (2008). Metode Penelitian Pendidikan. Bandung: Remaja Rosdakarya

[8] Smith, F. (2004). Understanding reading: A psycholinguistic analysis of reading and learning to read (6th ed). Mahwah, N.J: Lawrence Erlbaum Associates Publishers

[9] Kusumawati, F. P. and Sari, R. P. (2019). Developing Speaking Material for Teaching Speaking Based on Communicative Language Teaching for Second Semester Students of English Education Study Program Muhammadiyah University of Metro. Intensive Journal, 2(1)

Retrieved from http://ois.uniskaim.ac.id/index.php/EJB

[10] Harwood, N. (2010). Issues in Materials Development and Design. Cambridge University Press

[11] Kusumawati, F.P. (2017). Developing English Learning Material for Speaking Skill Based on ADDIE. Premise Jornal, 6(1)

[12] Sinaga, D. S. (2018). Developing English Speaking Materials Based on Task-Based Learning for Eight Grade of Junior High School. Bachelor Thesis. University of Muhammadiyah Sumatera Utara 